\title{
Type Curves Relating Well Spacing and Heterogeneity to Oil Recovery in a Water Flooded Reservoir-A Case Study
}

\author{
R. Trabelsi, F. Boukadi, J. Lee, B. Boukadi, A. Seibi, H. Trabelsi \\ Department of Petroleum Engineering, University of Louisiana, Lafayette, USA \\ Email: rfb2942@louisiana.edu
}

How to cite this paper: Trabelsi, R., Boukadi, F., Lee, J., Boukadi, B., Seibi, A. and Trabelsi, H. (2017) Type Curves Relating Well Spacing and Heterogeneity to Oil Recovery in a Water Flooded Reservoir-A Case Study. Natural Resources, 8, 632-645. https://doi.org/10.4236/nr.2017.810040

Received: April 13, 2017

Accepted: October 28, 2017

Published: October 31, 2017

Copyright (c) 2017 by authors and Scientific Research Publishing Inc. This work is licensed under the Creative Commons Attribution International License (CC BY 4.0).

http://creativecommons.org/licenses/by/4.0/

\section{(c) (i) Open Access}

\begin{abstract}
The design of an optimum spacing between oil wells entails both reservoir characterization and economics considerations. High hydrocarbon recovery requires short distances between wells. However, higher well density leads to a greater development cost. Accordingly, determination of an optimum well spacing is primordial in the development of oil fields. As a matter of fact, the identification of optimum well spacing for heterogeneous sandstone reservoirs undergoing waterflooding requires extensive analytical and numerical studies. The intent of this work is therefore to develop type curves as a quick tool in estimating ultimate recovery and reduce excessive reservoir simulation cost in analog reservoirs. These type curves utilize reservoir heterogeneity and well spacing in the estimating of oil recovery. In this work, we investigated numerically the effects of heterogeneity and well spacing on ultimate recovery using Eclipse black oil simulation and PEEP economic software 2015 and 2009 versions, respectively. The study involved a $50-\mathrm{ft}$ thick Middle Eastern reservoir with porosity variability ranging from 0.2 to 0.9 . Corresponding average matrix permeabilities of 1,10 and 100 md were considered. Type curves relating well spacing and heterogeneity to ultimate oil recovery were developed. Type curves and net present value calculations indicated that there is exists an ultimate well spacing for each of the considered matrix permeabilities.
\end{abstract}

\section{Keywords}

Type Curves, Permeability, Recovery, Well Spacing, Heterogeneity

\section{Introduction}

Proper distribution of wells in a reservoir undergoing waterflooding leads to both low cost and high sweep efficiency, which yields higher recovery. For an 
injector-producer pair, the sweep efficiency, controlled by heterogeneity, plays a major role in determining the optimum well placement.

Well spacing is defined as the acreage of the productive area divided by the total number of wells in the same area presented in terms of acres/well. Well spacing has been the main concern for the industry for many years. $\mathrm{Wu}$, Laughlin, and Lardon [1] investigated well spacing and looked at the effect of oil recovery by injecting water. According to their study, a decrease in well spacing from 40 to 20 acres can increase the recovery by up to $9 \%$.

It has also been proven that the lower the spacing between the producing wells, the higher the recovery (Bobar [2]; Matthews, Carter, and Dake [3]; Roberts [4]; and Beckner and Song [5]). However, increasing number of completed wells in a field depends solely on the economics of the development. Interference might be another factor that affects the oil recovery with respect to well spacing. As number of wells increases, interference becomes significant and therefore lower recovery is obtained.

In the early days, when the concept of proper adjustment of wells for an optimum reservoir development was not yet well defined, the wells were completed with wider spacing. That was because ultimate recovery was considered to be independent of well spacing (Kern [6] and Seifert, Lewis, Hern, and Steel [7]).

However, other authors have indicated that closer well spacing leads to an additional oil recovery ranging from $2 \%$ to up to $14 \%$ depending upon reservoir quality, drive mechanism and production practices. For water flooding, up to $70 \%$ of the oil-originally-in-place (OIIP) will be produced when reducing the well spacing to optimized distances (Sloan [8], Chacon [9], Christman [10], and Levey and Sippel [11]).

So, it is fair to say that maximizing oil recovery is a complicated and controversial process and does not depend on well spacing alone and that many other factors have to be considered. Many authors have concluded that increase in recovery depends on reservoir characteristics such as reservoir quality, i.e. heterogeneity, permeability, porosity, connectivity, drive mechanism, relative permeability, injectivity, productivity, and production practices (Johen, Al-Qabandi, and Anderson [12]).

A few authors indicated that fluid properties, sweep efficiency and net pay are major factors that could affect oil recovery to some extent. They added that project economics has to also be tied up to rock and fluid properties (Tokunaga and Hise [13]; and Malik, Silva, Brimhall, and Wu [14]).

It was also concluded that recovery efficiency correlates well with permeability and to lesser degree with connate water saturation and also shows good fit with the size of the reservoir (Kern [6]). Tokunaga and Hise [13] have also indicated that besides well spacing and other rock and fluid properties economic analysis is a key factor in optimizing oil recovery from heterogeneous reservoirs.

Suarez and Pichon [15] indicated that one of the more critical questions that any asset team must consider concerns well spacing when designing the devel- 
opment plan for a new field. They added that well spacing defines the total number of wells, the drilling and completion schedule, and the field-production curve. They also noted that the ultimate decision relies on economic analysis and balancing the expected ultimate recovery against capital and operational expenditures.

So, most authors agree that oil recovery depends on reservoir heterogeneity and well spacing. The following methodology is an illustration of heterogeneity characterization and well spacing definition.

\section{Methodology}

\subsection{Heterogeneity Characterization}

In order to study the effects of heterogeneity on oil recovery, permeability was generated from porosity measurements (Figures 1-3). Neutron porosity logs were ran in many wells and porosities were recorded at different depths. The porosity data bank was converted to permeabilities using the following formula:

$$
k=a 10^{f b}
$$

where " $a$ " and " $b$ " are correlation coefficients; 0.005 and 25, respectively, $k$ is permeability and $\phi$ is porosity; in md and fractions, respectively. Three average

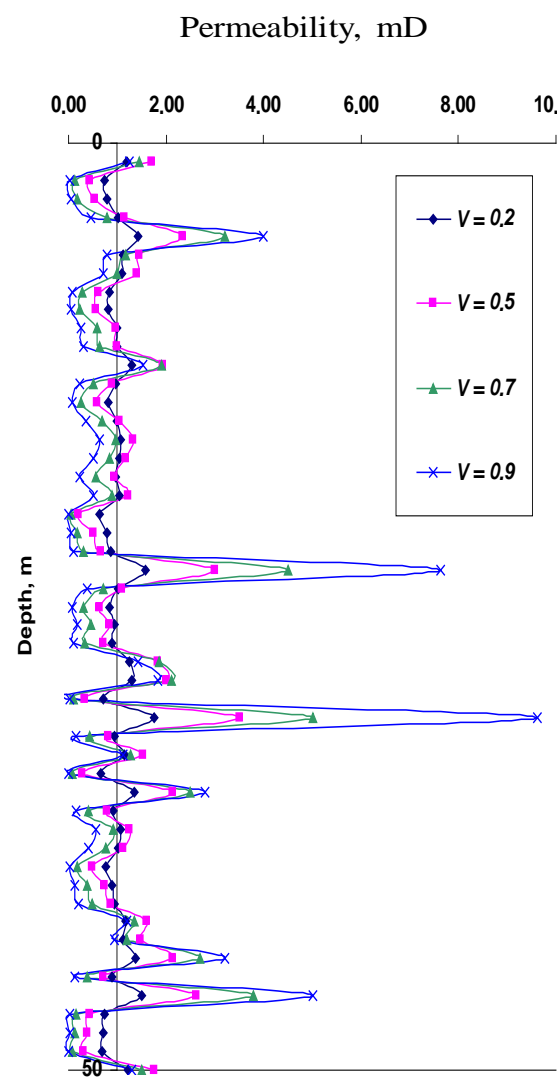

(a)
Porosity, fraction

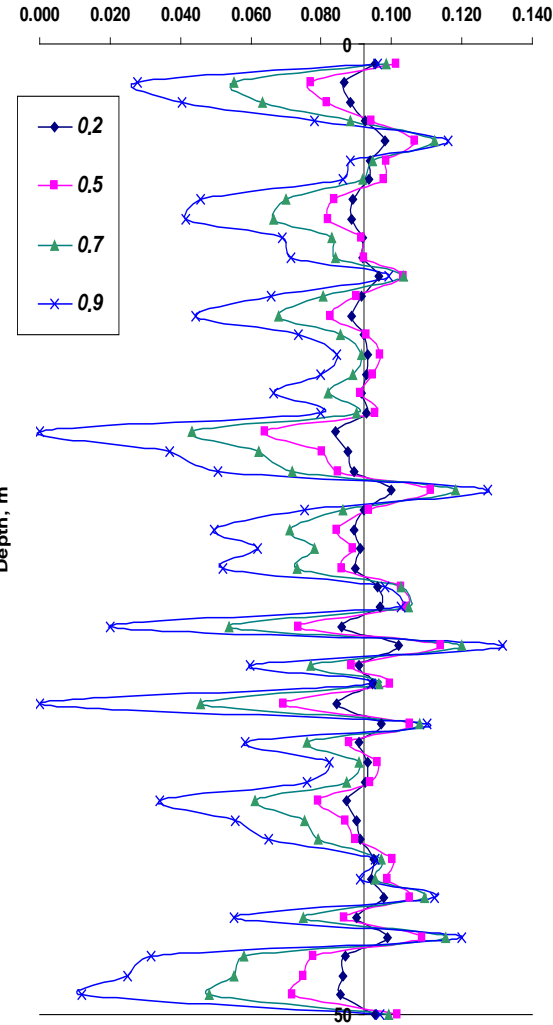

(b)

Figure 1. Generated permeability. (a) From porosity distribution; (b) Average permeability $=1 \mathrm{mD}$, different $\mathrm{V}$. 
Permeability, mD

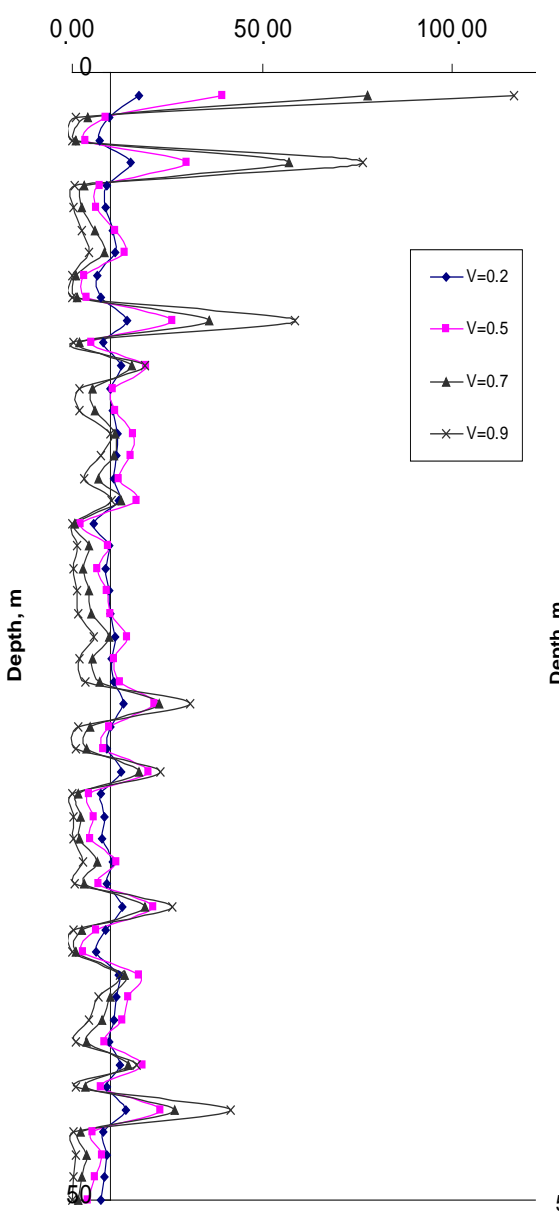

(a)
Porosity, fraction

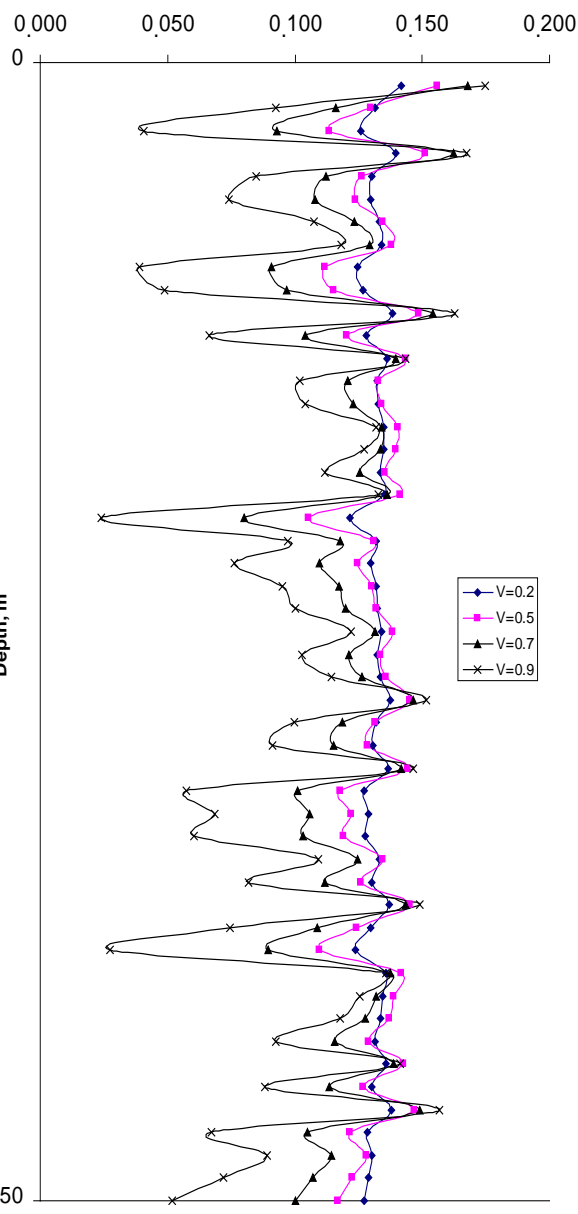

(b)

Figure 2. Generated permeability. (a) From porosity distribution; (b) Average permeability $=10 \mathrm{mD}$, different $\mathrm{V}$.

permeability ranges (classes) of 1, 10 and 100 md have been identified (Figures 1-3).

To characterize heterogeneity, Dykstra-Parsons [16] proposed a method that estimates a permeability variation coefficient $(\mathrm{V})$ using the following equation:

$$
V=\frac{\bar{k}-k_{\sigma}}{\bar{k}}
$$

Permeability, $k$, was plotted on a log-probability paper (see Figure 1 ); with $k$ as permeability with $50 \%$ probability and $k_{\sigma}$ as permeability with $84.1 \%$ probability. Figure 4 and Figure 5 illustrate the fact that four different variation coefficients $(0.2,0.5,0.7$ and 0.9$)$ were identified from permeability frequency plots for each class of permeability. The higher the variation coefficient is the higher the degree of heterogeneity.

To discretize heterogeneity and for dynamic modelling purposes, permeability maps have been generated for the 3 different permeability classes $(1,10$, and 100 md) and exported as input to the developed Eclipse data files. 
Permeability, $\mathrm{mD}$

Porosity, fraction

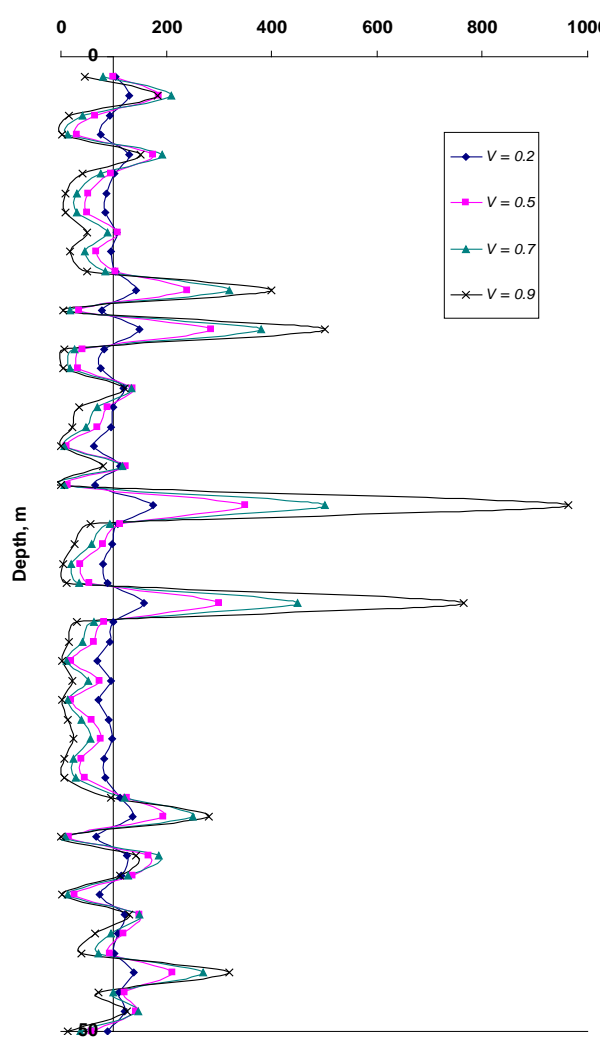

(a)

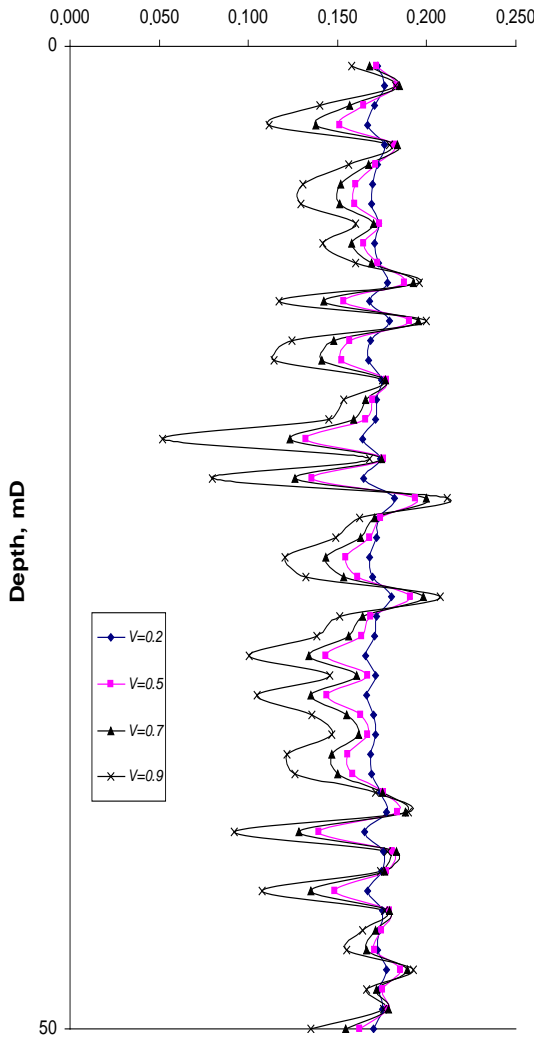

(b)

Figure 3. Generated permeability. (a) From porosity distribution; (b) Average permeability $=100 \mathrm{mD}$, different $\mathrm{V}$.

\subsection{Well Spacing Definition}

To study the effect of well spacing on oil recovery, data files using $15 \times 40 \times 50$ grid block system were developed. The injector and producer wells were arranged according to a line-drive process (see Figure 6). Other injector-producer placement options have been tested and line drive was the best adopted waterflood scheme.

The distance between the injector and producing lines was kept at $820 \mathrm{ft}$ (250 $\mathrm{m})$. Two more wells were added longitudinally each time by infill drilling, reducing well spacing between like wells (injector to injector and producer to producer). At the end, 28 wells were input into the model for a total number of 168 simulation runs.

Figure 7 displays a schematic of the adopted infill drilling process to move from 8 to 16 -like wells. All sensitivity cases were simulated for a 30 -year production period.

\section{Results and Discussion}

To study the effects of heterogeneity and well spacing on oil recovery, a sensitivity analysis involving different permeability variability coefficients $\mathrm{V}(0.0,0.2$, $0.5,0.7$ and 0.9 ) for average matrix permeabilities of 1,10 and $100 \mathrm{md}$ at 


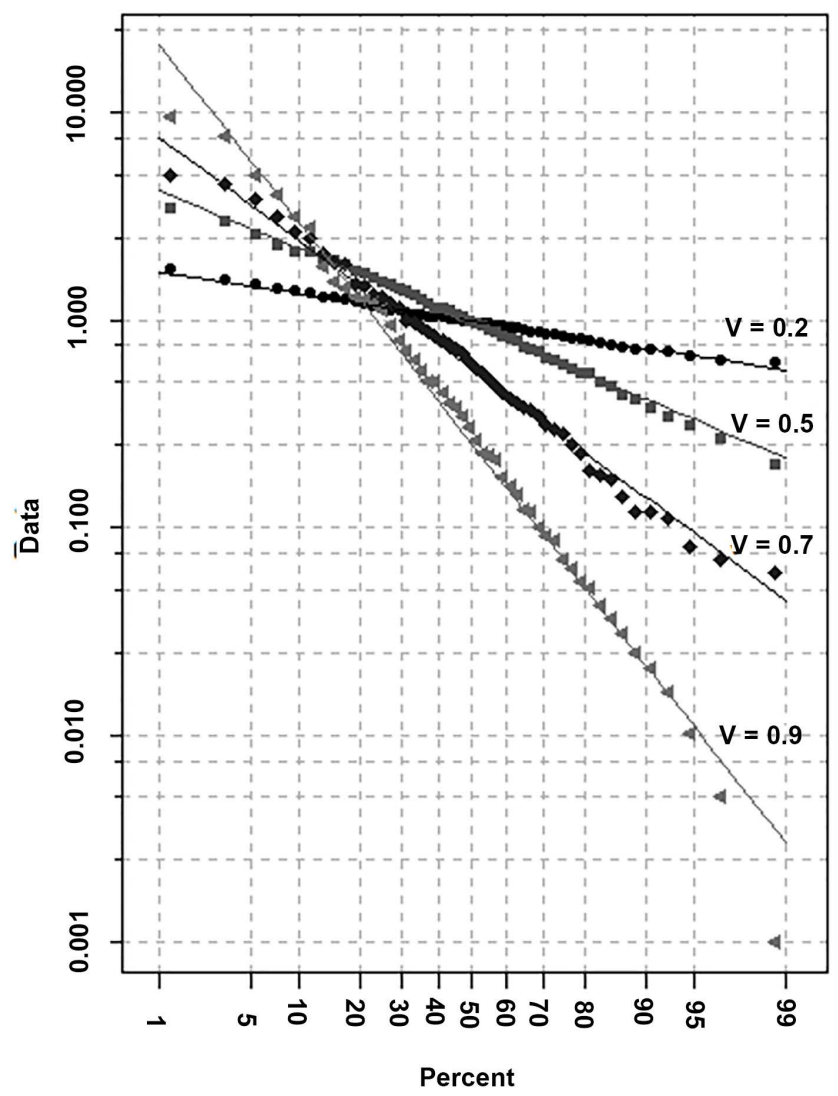

(a)

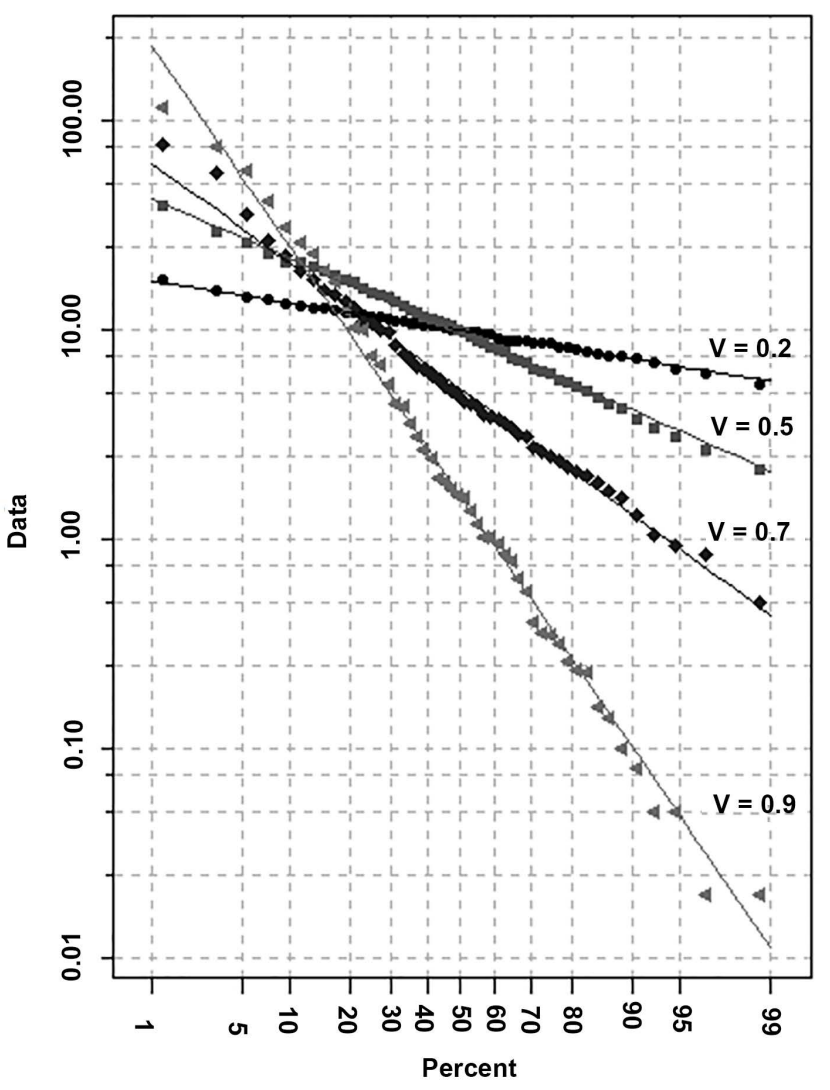

(b)

Figure 4. Permeability variation coefficient $V$ [Average permeability $=1 \mathrm{mD}$ (a) \& $10 \mathrm{mD}$ (b)].

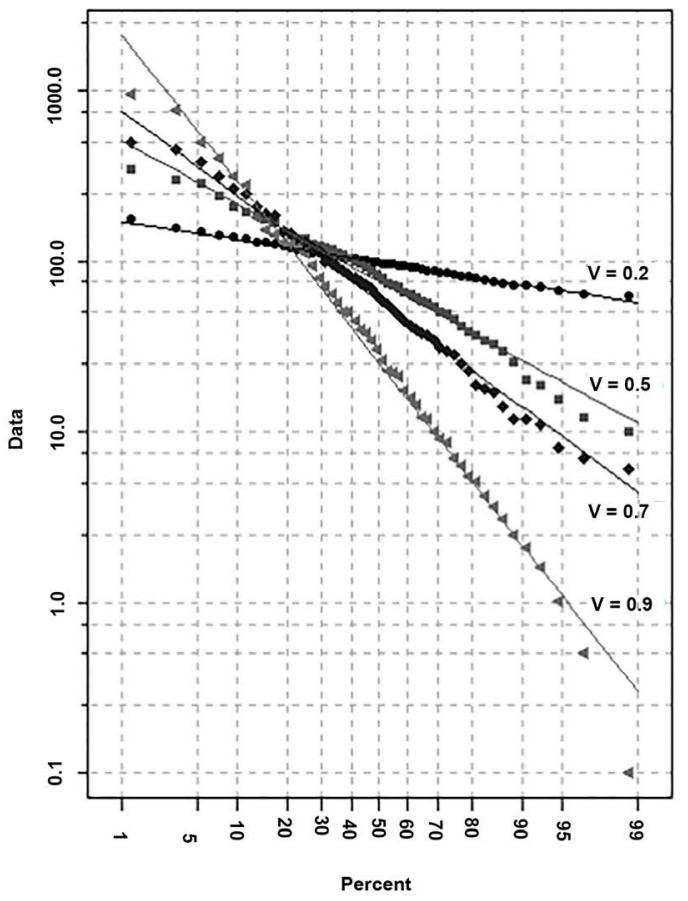

Figure 5. Permeability variation coefficient $V$ (Average permeability $=100 \mathrm{mD})$. 


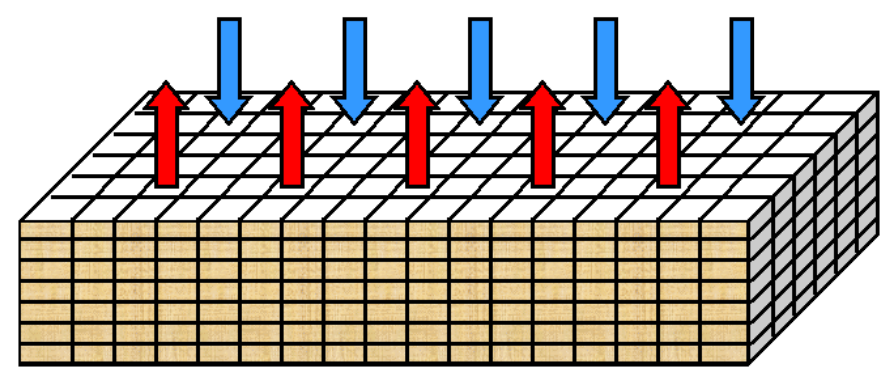

Figure 6. A schematic of the static model (5 injector/5 producer line-drive).

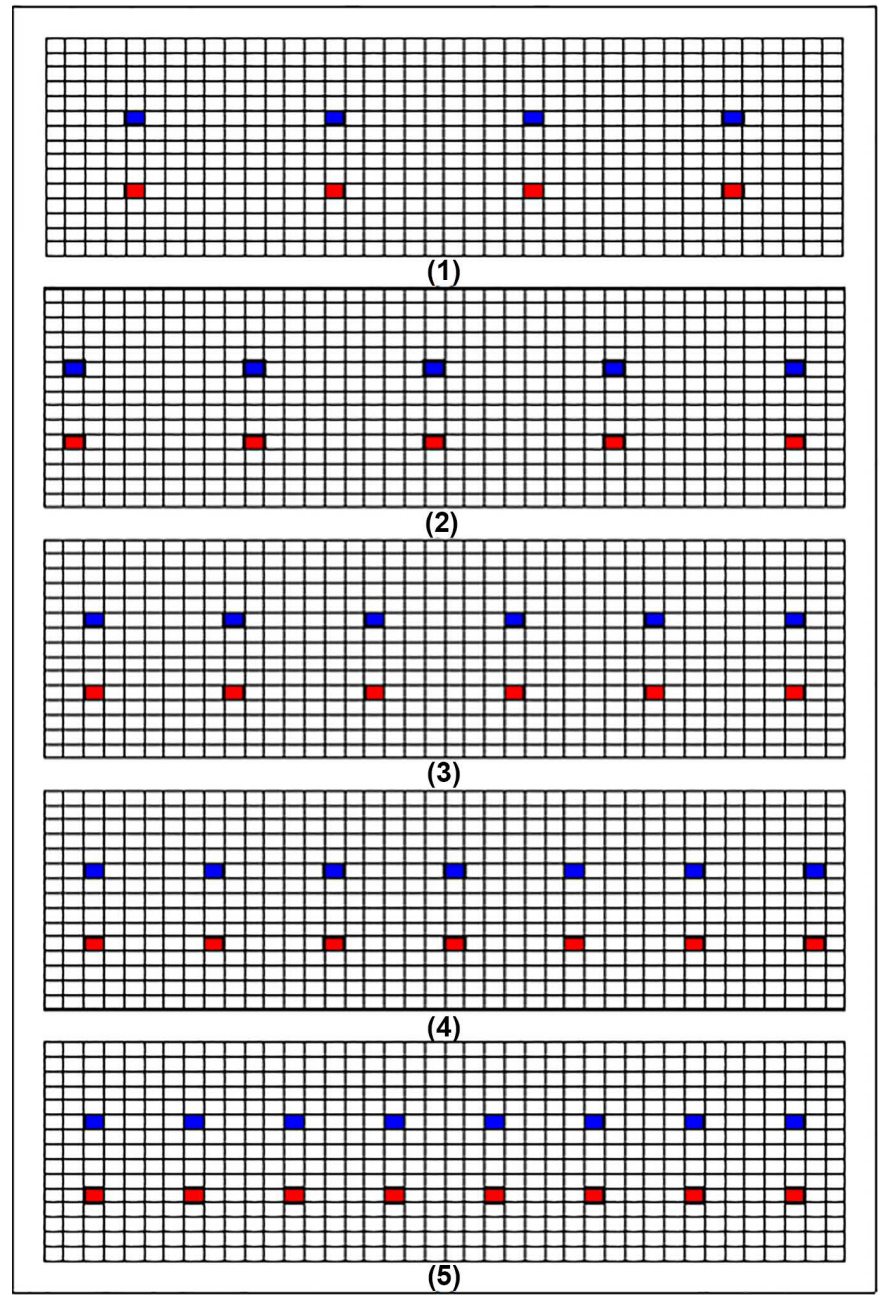

Figure 7. Schematics portraying systematic infill drilling process. Diagrams (1) to (5) illustrate process of moving from 8 to 16 like-wells.

different well spacing was done. Table 1 summarizes the adopted permeability variability experimental settings. A total of 210 experiments were done. Seventy experiments for each permeability class; using well spacing of 13 to $185 \mathrm{~m}$ and variabilities of $0,0.2,0.5,0.7$ and 0.9 , were performed.

Oil recovery following waterflooding was simulated for 30 years for all possible combinations (Figures 8-10). Increased variability led to lower recoveries 
Table 1. Executed Experiments for $\mathrm{k}=1,10$, and $100 \mathrm{md}$.

\begin{tabular}{|c|c|c|c|c|c|}
\hline \multirow{2}{*}{$\begin{array}{c}\text { Well Spacing } \\
\text { (acres/well) } \\
185\end{array}$} & \multicolumn{5}{|c|}{ Permeability Variability } \\
\hline & $\mathrm{V}=0.0$ & $\mathrm{~V}=0.2$ & $\mathrm{~V}=0.5$ & $\mathrm{~V}=0.7$ & $\mathrm{~V}=0.9$ \\
\hline 93 & $\mathrm{~V}=0.0$ & $\mathrm{~V}=0.2$ & $\mathrm{~V}=0.5$ & $\mathrm{~V}=0.7$ & $\mathrm{~V}=0.9$ \\
\hline 62 & $\mathrm{~V}=0.0$ & $\mathrm{~V}=0.2$ & $\mathrm{~V}=0.5$ & $\mathrm{~V}=0.7$ & $\mathrm{~V}=0.9$ \\
\hline 46 & $\mathrm{~V}=0.0$ & $\mathrm{~V}=0.2$ & $\mathrm{~V}=0.5$ & $\mathrm{~V}=0.7$ & $\mathrm{~V}=0.9$ \\
\hline 37 & $\mathrm{~V}=\mathbf{0 . 0}$ & $\mathrm{V}=0.2$ & $\mathrm{~V}=0.5$ & $\mathrm{~V}=0.7$ & $\mathrm{~V}=0.9$ \\
\hline 31 & $\mathrm{~V}=\mathbf{0 . 0}$ & $\mathrm{V}=0.2$ & $\mathrm{~V}=0.5$ & $\mathrm{~V}=0.7$ & $\mathrm{~V}=0.9$ \\
\hline 26 & $\mathrm{~V}=0.0$ & $\mathrm{~V}=0.2$ & $\mathrm{~V}=0.5$ & $\mathrm{~V}=0.7$ & $\mathrm{~V}=0.9$ \\
\hline 23 & $\mathrm{~V}=0.0$ & $\mathrm{~V}=0.2$ & $\mathrm{~V}=0.5$ & $\mathrm{~V}=0.7$ & $\mathrm{~V}=0.9$ \\
\hline 21 & $\mathrm{~V}=\mathbf{0 . 0}$ & $\mathrm{V}=0.2$ & $\mathrm{~V}=0.5$ & $\mathrm{~V}=0.7$ & $\mathrm{~V}=0.9$ \\
\hline 19 & $\mathrm{~V}=\mathbf{0 . 0}$ & $\mathrm{V}=0.2$ & $\mathrm{~V}=0.5$ & $\mathrm{~V}=0.7$ & $\mathrm{~V}=0.9$ \\
\hline 17 & $\mathrm{~V}=\mathbf{0 . 0}$ & $\mathrm{V}=0.2$ & $\mathrm{~V}=0.5$ & $\mathrm{~V}=0.7$ & $\mathrm{~V}=0.9$ \\
\hline 15 & $\mathrm{~V}=0.0$ & $\mathrm{~V}=0.2$ & $\mathrm{~V}=0.5$ & $\mathrm{~V}=0.7$ & $\mathrm{~V}=0.9$ \\
\hline 14 & $\mathrm{~V}=0.0$ & $\mathrm{~V}=0.2$ & $\mathrm{~V}=0.5$ & $\mathrm{~V}=0.7$ & $\mathrm{~V}=0.9$ \\
\hline 13 & $\mathrm{~V}=0.0$ & $\mathrm{~V}=0.2$ & $\mathrm{~V}=0.5$ & $\mathrm{~V}=0.7$ & $\mathrm{~V}=0.9$ \\
\hline
\end{tabular}

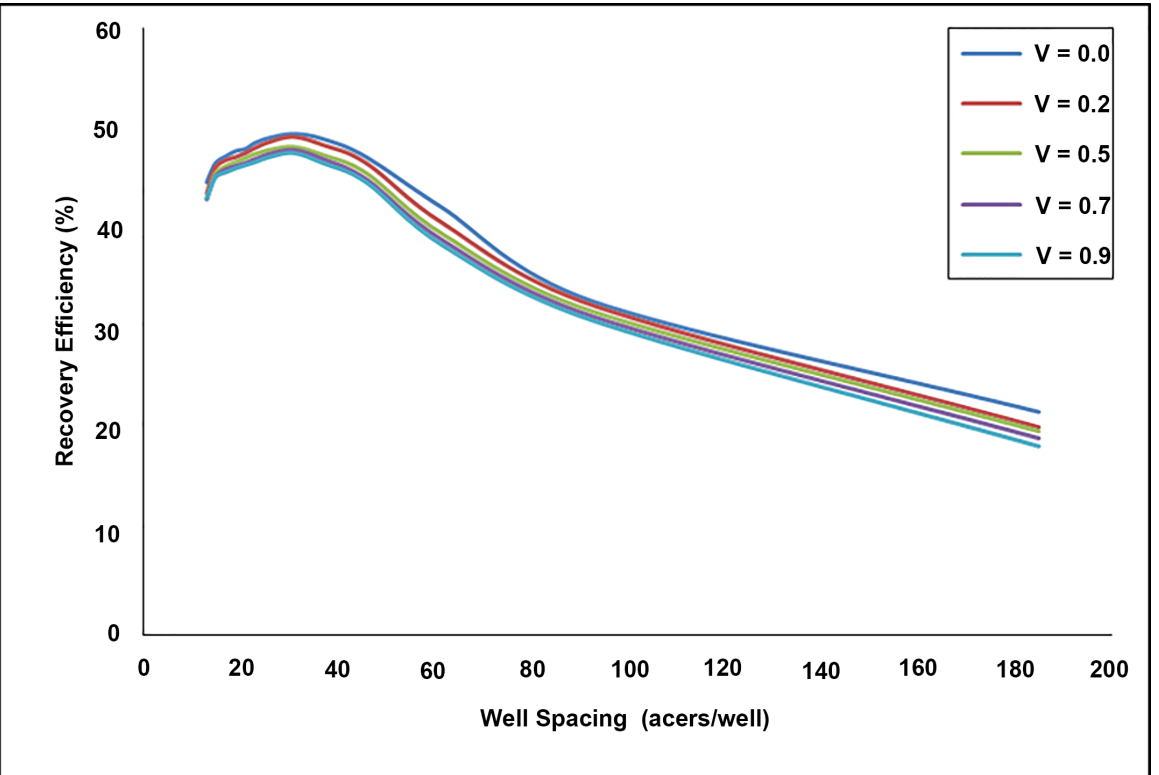

Figure 8. Recovery efficiency for average permeability case of $1 \mathrm{mD}$.

and this is consistent with Babadagli findings [17]. Optimum well spacing would, however, mitigate such a decline in waterflooding recovery. Figures 8, 9, and 10 illustrate the fact that recovery efficiency observes a peak at a specific well spacing and that an optimum well spacing can then be determined given a degree of heterogeneity and an average matrix permeability. 


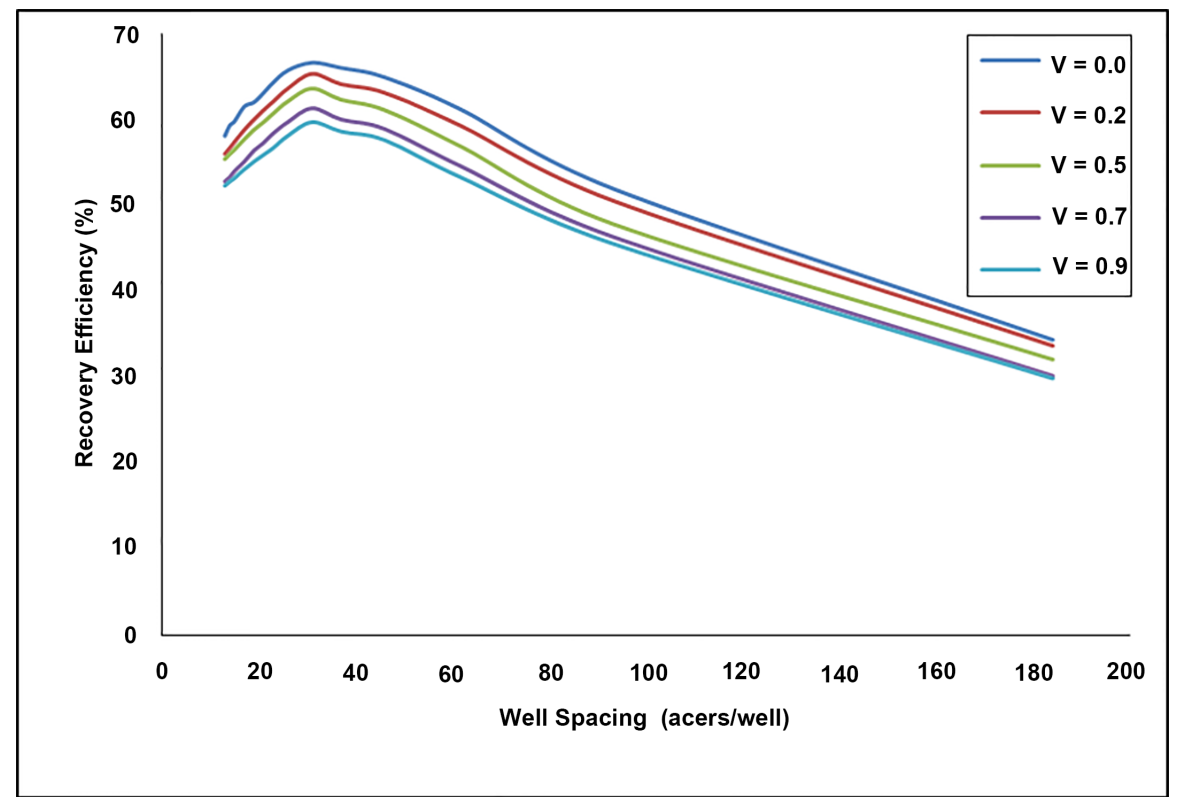

Figure 9. Recovery efficiency for average permeability case of $10 \mathrm{mD}$.

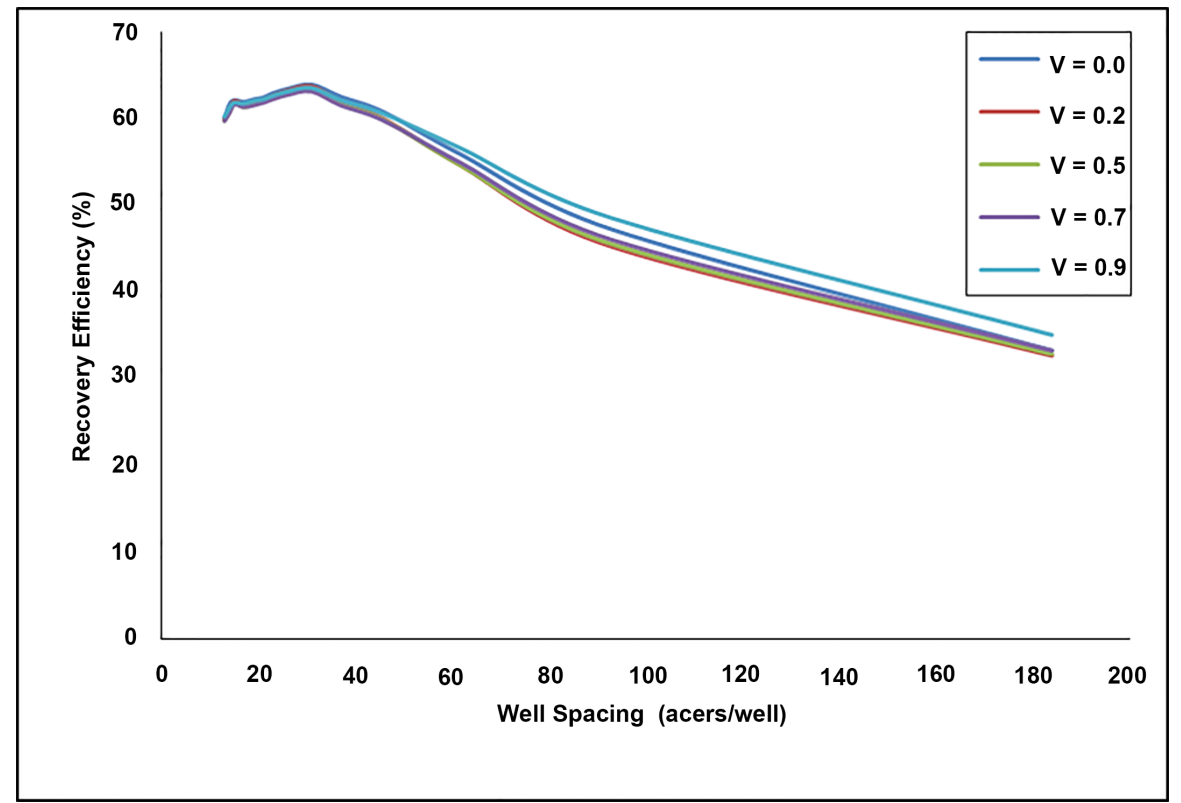

Figure 10. Recovery efficiency for average permeability case of $100 \mathrm{mD}$.

Figure 8 indicates that the optimum well spacing for a peak oil recovery was found at 31 acres/well for a matrix permeability in the vicinity of $1 \mathrm{mD}$ and that oil recovery decreases with increasing heterogeneity. Recovery efficiency ranged from a high of $49.5 \%$ at a spacing of 31 cares/well and a 0 variability to a low of $18.6 \%$ at a spacing of 185 acres/well and a variability of 0.9 .

The same can be observed for a matrix permeability in the neighborhood of 10 $\mathrm{mD}$. Recovery numbers are, however, higher due to a higher productivity and a stable waterflood displacement front. For this case, recovery ranged from a high of $66.6 \%$ at a spacing of 31 cares/well and a 0 variability to a low of $29.9 \%$ at a 
spacing of 185 acres/well and a variability of 0.9 .

The same cannot be said for a matrix permeability in the vicinity of $100 \mathrm{mD}$. Recovery observed a peak of $63.9 \%$ at a spacing of 31 acres/well and a 0 variability and a low of $32.6 \%$ for a larger spacing of 185 acres/well and a variability of 0.2. This can be triggered by fingering in the high permeability streaks and an unstable water displacement front.

Results were verified with the following series of well logs (see Figure 11) taken into account one of the producers with an average matrix permeability of $100 \mathrm{md}$ and a variability of 0.7 , at a given point in time of the waterflooding operation.

The viewgraphs (1) to (9) of a post-waterflood resistivity log ran on one of the wells indicate that water displacement (purple) is not uniform due to the high degree of heterogeneity $(\mathrm{V}=0.7)$. The graphs also show that the oil bank (light blue) is bypassed in layers with higher permeability and as a result, recovery is low.

\section{Case Study Economics}

Besides well spacing and the degree of reservoir heterogeneity, oil recovery optimization involves the study of economics. Net present value (NPV) was utilized in the feasibility study of each of the tested scenarios. NPV is defined as the difference between the present value of a future net income and the present value of the total capital expenditure. This parameter was obtained using PEEP.

Table 2 summarizes the adopted NPV experimental settings. A total of 210 experiments were done. Seventy experiments for each permeability class; using well spacing of 13 to $185 \mathrm{~m}$ and variabilities of $0,0.2,0.5,0.7$ and 0.9 , were performed.

Figures 12-14 show the resulting relationship between NPV, permeability variability and well spacing. In the figures, only variabilities of $0.2,0.5,0.7$ and 0.9 were considered. The figures indicate that there exists an optimum NPV for each permeability variability and well spacing.

It is important to say that spacing decision should be based on NPV calculations. It was found that for a matrix permeability in the range of $1 \mathrm{mD}$, highest NPVs are achieved at a spacing of 37 acres/well for permeability variabilities of $0.2,0.5,0.7$, and 0.9 (Figure 12).

Figure 13 also shows that the optimum well spacing for a matrix permeability of $10 \mathrm{mD}$ is 31 acres/well. NPV at that spacing reaches a maximum for variabilities of $0.2,0.5,0.7$, and 0.9 .

For matrix permeability in the vicinity of $100 \mathrm{mD}$, Figure 14 indicates that a closer spacing will maximize NPV. Optimum spacing of 17 acres/well is needed for a variability of $0.2,0.5,0.7$, and 0.9 . The high net present value is mainly caused by the early high recovery from high permeability streaks with closer spacing and a favorable mobility ratio. 
Table 2. Executed Experiments for $\mathrm{k}=1,10$, and $100 \mathrm{md}$.

\begin{tabular}{|c|c|c|c|c|c|}
\hline \multirow{2}{*}{$\begin{array}{c}\text { Well Spacing } \\
\text { (acres/well) } \\
185\end{array}$} & \multicolumn{5}{|c|}{ Net Present Value } \\
\hline & $\mathrm{V}=0.0$ & $\mathrm{~V}=0.2$ & $\mathrm{~V}=0.5$ & $\mathrm{~V}=0.7$ & $\mathrm{~V}=0.9$ \\
\hline 93 & $\mathrm{~V}=0.0$ & $\mathrm{~V}=0.2$ & $\mathrm{~V}=0.5$ & $\mathrm{~V}=0.7$ & $\mathrm{~V}=0.9$ \\
\hline 62 & $\mathrm{~V}=0.0$ & $\mathrm{~V}=0.2$ & $\mathrm{~V}=0.5$ & $\mathrm{~V}=0.7$ & $\mathrm{~V}=0.9$ \\
\hline 46 & $\mathrm{~V}=0.0$ & $\mathrm{~V}=0.2$ & $\mathrm{~V}=0.5$ & $\mathrm{~V}=0.7$ & $\mathrm{~V}=0.9$ \\
\hline 37 & $\mathrm{~V}=0.0$ & $\mathrm{~V}=0.2$ & $\mathrm{~V}=0.5$ & $\mathrm{~V}=0.7$ & $\mathrm{~V}=0.9$ \\
\hline 31 & $\mathrm{~V}=0.0$ & $\mathrm{~V}=0.2$ & $\mathrm{~V}=0.5$ & $\mathrm{~V}=0.7$ & $\mathrm{~V}=0.9$ \\
\hline 26 & $\mathrm{~V}=0.0$ & $\mathrm{~V}=0.2$ & $\mathrm{~V}=0.5$ & $\mathrm{~V}=0.7$ & $\mathrm{~V}=0.9$ \\
\hline 23 & $\mathrm{~V}=0.0$ & $\mathrm{~V}=0.2$ & $\mathrm{~V}=0.5$ & $\mathrm{~V}=0.7$ & $\mathrm{~V}=0.9$ \\
\hline 21 & $\mathrm{~V}=0.0$ & $\mathrm{~V}=0.2$ & $\mathrm{~V}=0.5$ & $\mathrm{~V}=0.7$ & $\mathrm{~V}=0.9$ \\
\hline 19 & $\mathrm{~V}=0.0$ & $\mathrm{~V}=0.2$ & $\mathrm{~V}=0.5$ & $\mathrm{~V}=0.7$ & $\mathrm{~V}=0.9$ \\
\hline 17 & $\mathrm{~V}=0.0$ & $\mathrm{~V}=0.2$ & $\mathrm{~V}=0.5$ & $\mathrm{~V}=0.7$ & $\mathrm{~V}=0.9$ \\
\hline 15 & $\mathrm{~V}=0.0$ & $\mathrm{~V}=0.2$ & $\mathrm{~V}=0.5$ & $\mathrm{~V}=0.7$ & $\mathrm{~V}=0.9$ \\
\hline 14 & $\mathrm{~V}=0.0$ & $\mathrm{~V}=0.2$ & $\mathrm{~V}=0.5$ & $\mathrm{~V}=0.7$ & $\mathrm{~V}=0.9$ \\
\hline 13 & $\mathrm{~V}=0.0$ & $\mathrm{~V}=0.2$ & $\mathrm{~V}=0.5$ & $\mathrm{~V}=0.7$ & $\mathrm{~V}=0.9$ \\
\hline
\end{tabular}

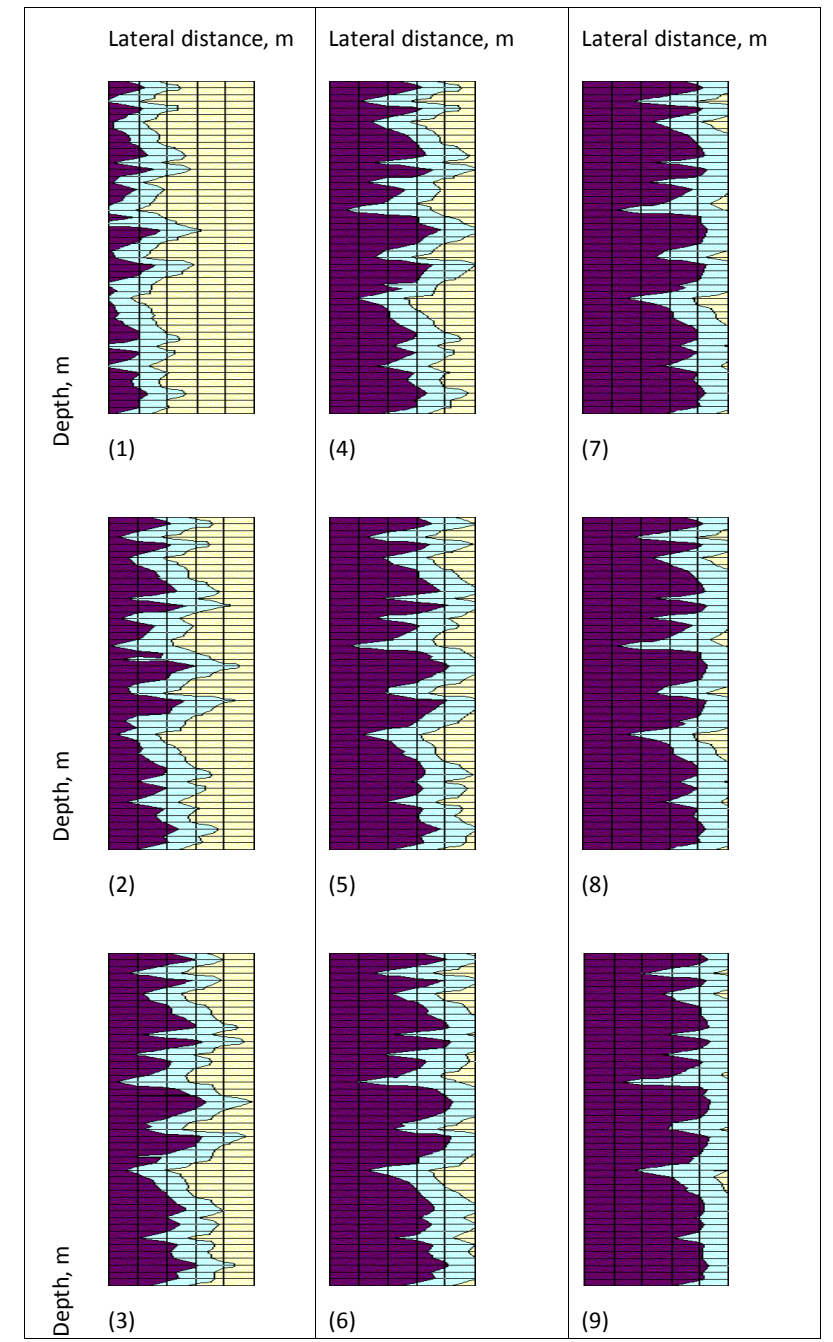

Figure 11. Shows effects of heterogeneity on sweep efficiency (Average permeability of $100 \mathrm{mD}$ and $\mathrm{V}=0.7$ ). 


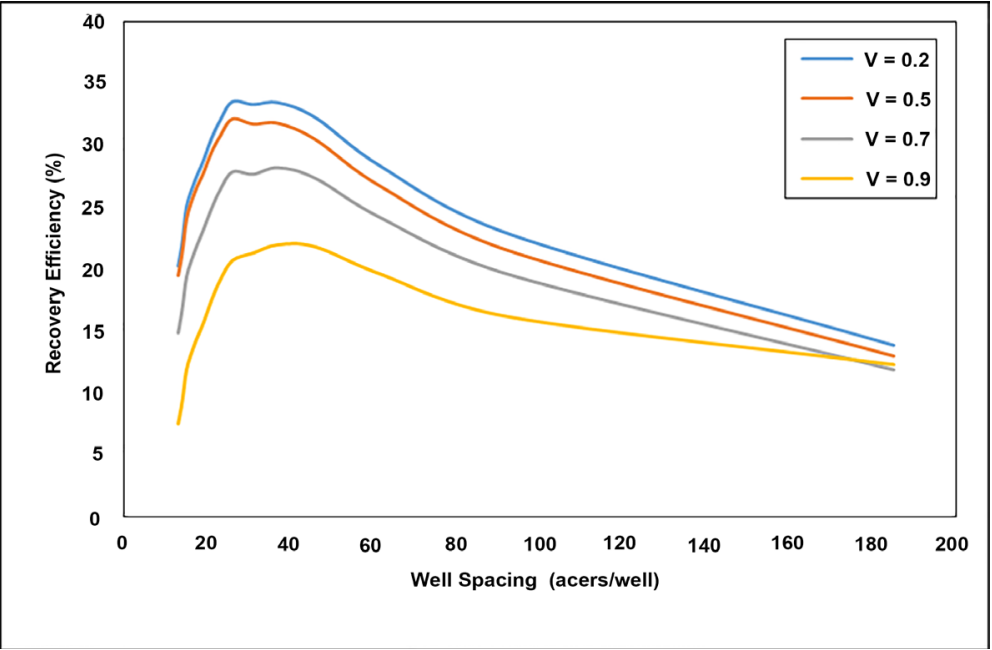

Figure 12. NPV for average permeability case of $1 \mathrm{mD}$.

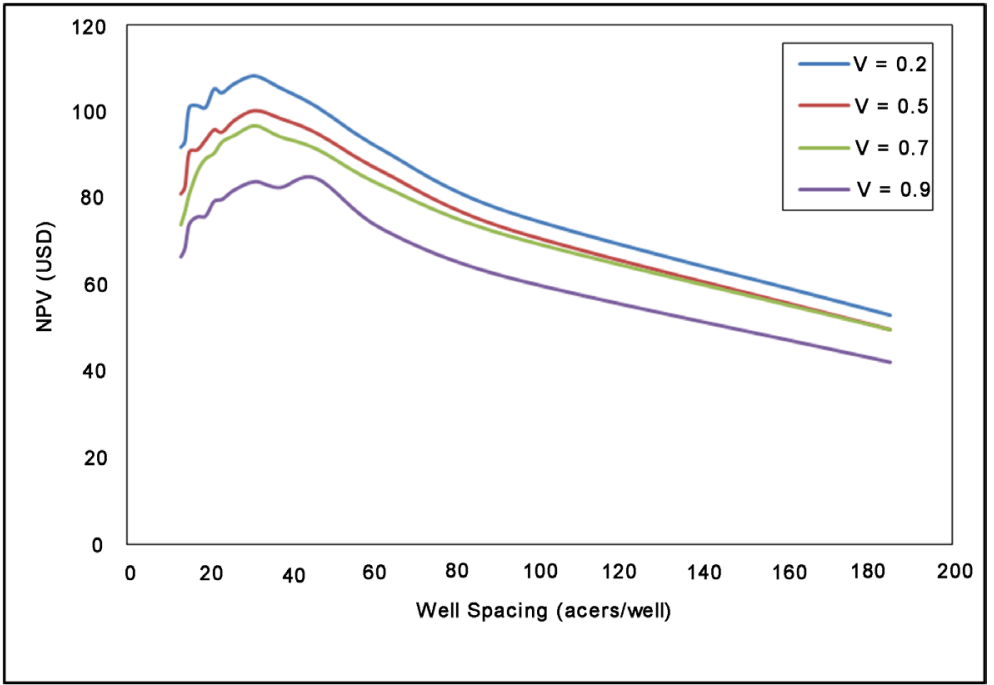

Figure 13. NPV for average permeability case of $10 \mathrm{mD}$.

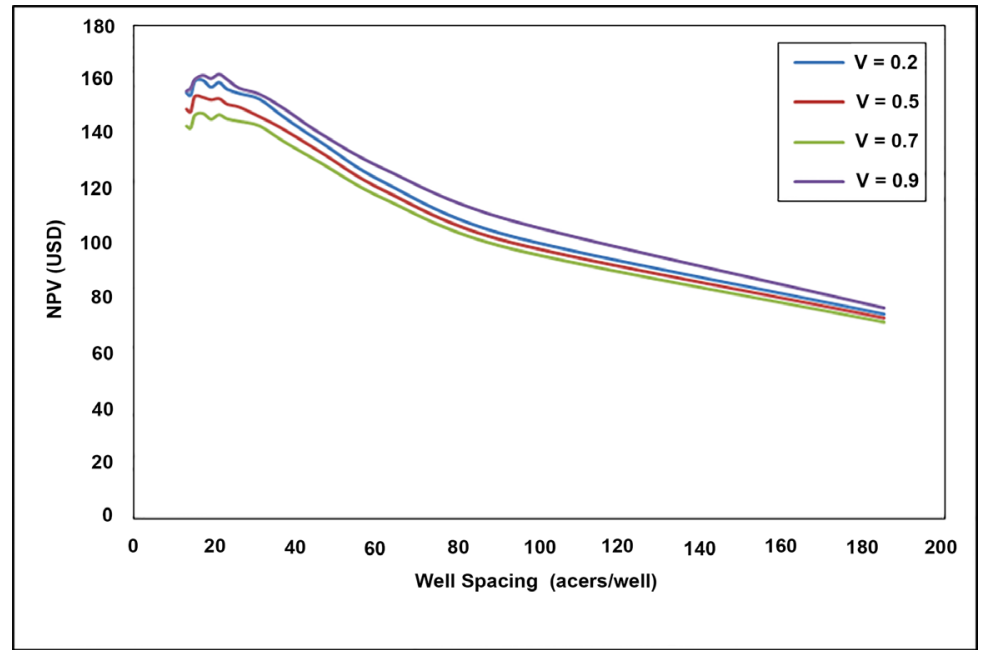

Figure 14. NPV for average permeability case of $100 \mathrm{mD}$. 


\section{Conclusion}

Type curves have been developed for sandstone reservoirs undergoing waterflooding. The curves apply for analog reservoirs with a porosity range of 0.2 to 0.9 and corresponding permeability classes of 1,10 , and $100 \mathrm{md}$. A field-scale waterflooding performance model for a Middle Eastern heterogeneous reservoir was used as a base case. Reservoir simulation results indicated that recovery efficiency decreases as permeability variability increases. Based on NPV calculations, it was also concluded that there exists an optimum well spacing for all tested permeability variabilities. Well spacings of 37, 31, and 17 acres/well for permeability matrix values of 1,10 and $100 \mathrm{mD}$ maximized the field NPV.

\section{References}

[1] Wu, C.H., Laughlin, B.A. and Jardon, M. (1989) Infill Drilling Enhances Waterflooding Recovery. Journal of Petroleum Technology, 41, 1088-1094. https://doi.org/10.2118/17286-PA

[2] Bobar, A.R. (1985) Reservoir Engineering Concepts on Well Spacing. Society of Petroleum Engineers Paper \# 15338, 29 pages.

[3] Matthews, J.D., Carter, J.N. and Dake, L.P. (1992) Investigation of Optimum Well Spacing for North Sea Eocene Reservoirs. Proceedings of the European Petroleum Conference, Cannes, 16-18 November 1992, 143-152. https://doi.org/10.2118/25030-MS

[4] Roberts, T. (1961) Economics of Well Spacing. Society of Petroleum Engineers Paper \# 240, 10 Pages.

[5] Beckner, B.L. and Song, X. (1995). Field Development Planning Using Simulated Annealing-Optimal Economic Well Scheduling and Placement. Proceedings of the Annual Technical Conference and Exhibition, Dallas, 22-25 October 1995, 209-221. https://doi.org/10.2118/30650-MS

[6] Kern, L.R. (1981) Effects of Spacing on Waterflooding Recovery Efficiency. Society of Petroleum Engineers paper \# 10538, 31 Pages.

[7] Seifert, D., Lewis, J.J.M., Hern, C.Y. and Steel, N.C.T. (1996) Well Placement Optimization and Risking Using 3-D Stochastic Reservoir Modeling Techniques. Proceedings of the European 3-D Reservoir Modeling Conference, Stavanger, 16-17 April 1996, 289-300.

[8] Sloan, R.L. (1972) A Graph for Determining Reserves and Well Spacing. Journal of Petroleum Technology, 24, 1470-1472. https://doi.org/10.2118/4291-PA

[9] Chacon, F.H. (1973) Optimum Well Spacing for the Gas Reservoirs of Mexican Republic. Proceedings of the 48th Annual Fall Meeting of the Society of Petroleum Engineers of AIME, Las Vegas, 30 September-3 October 1973, 12 p.

[10] Christman, P.G. (1995) Modeling the Effects of Infill Drilling and Pattern Modification in Discontinuous Reservoirs. Society of Petroleum Engineers Reservoir Engineering Journal, 10, 4-9. https://doi.org/10.2118/27747-PA

[11] Levey, R.A. and Sippel, M.A. (1997) Determination of Well Spacing for Maximum Efficiency in Fluvial Gas Reservoirs Using Geostatistical Evaluation and Forward Stochastic Modeling, Proceedings of the Annual Technical Conference and Exhibition, San Antonio, 5-8 October 1997. https://doi.org/10.2118/38915-MS

[12] Jones, A.D.W., Al-Qabandi, S. and Anderson, S.A. (1995) Rapid Assessment of Pat- 
tern Waterflooding Uncertainty in a Giant Oil Reservoir. Proceedings of the Annual Technical Conference and Exhibition, San Antonio, 5-8 October 1997, 483-498.

[13] Tokunaga, H. and Hise, B.R. (1966) A Method to Determine Optimum Well Spacing. Proceedings of the Society of Petroleum Engineers California Regional Meeting, Santa Barbara, 17-18 November 1966, 7 p. https://doi.org/10.2118/1673-MS

[14] Malik, Z.A., Silva, B.A., Brimhall, R.M. and Wu, C.H. (1993) An Integrated Approach To Characterize Low Permeability Reservoir Connectivity for Optimal Waterflood Infill Drilling. Proceedings of the Society of Petroleum Engineers Rocky Mountain Regional/Low Permeability Reservoirs Symposium, Denver, 26-28 October 1993

[15] Suarez, M. and Pichon, S. (2016) Completion and Well-Spacing Optimization for Horizontal Wells in Pad Development in the Vaca Muerta Shale. Proceedings of the Society of Petroleum Engineers Argentina Exploration and Production of Unconventional Resources Symposium, Buenos Aires, 1-3 June 2016, 17 p. https://doi.org/10.2118/180956-MS

[16] Dykstra, H. and Parsons, R.L. (1950) The Prediction of Oil Recovery by Waterflooding in Secondary Recovery of Oil in the United States. 2nd Edition, API, Washington DC.

[17] Babadagli, T. (1999) Effect of Fractal Permeability Correlations on Waterflooding Performance in Carbonate Reservoirs. Journal of Petroleum Science and Engineering, 23, 223-238. https://doi.org/10.1016/S0920-4105(99)00023-6 